\title{
Le tweet stratégique: Use of Twitter as a PR tool by French politicians
}

\author{
Alex Frame*, Gilles Brachotte \\ University of Burgundy, Bd Gabriel, 21000 Dijon, France
}

\section{A R T I C L E I N F O}

\section{Article history:}

Received 29 July 2014

Received in revised form 2 November 2014

Accepted 10 November 2014

\section{Keywords:}

Communication strategy

France

Image management

Political PR

Social media

Twitter

\begin{abstract}
A B S T R A C T
This study, adopting a qualitative approach to political communication, looks in depth at the way Twitter is used as a PR tool by five French politicians. It suggests that the microblogging service plays a specific role in allowing them to monitor public opinion and current affairs, to interact with voters, journalists, stakeholders and other politicians and to disseminate information. The way politicians use Twitter is influenced by concerns of impression management (content and style of tweets), and also various institutional, political and social/symbolic limits, which contribute to reveal tensions between the field of French politics and the way it has shaped traditional political communication practises on the one hand, and the technical and social characteristics associated with Twitter on the other. While these characteristics may be factors encouraging politicians to adopt the microblogging platform as a PR tool, they also constitute challenges in terms of PR.
\end{abstract}

(C) 2014 Elsevier Inc. All rights reserved.

\section{Introduction}

In the course of the past five to six years, Twitter has rapidly imposed itself as one of the major digital PR tools used by politicians in many countries around the world. France is no exception, with around 60\% of French MPs active on Twitter during the last three months of 2013, according to a commercial study (Baron, 2014). ${ }^{1}$ The French general public has been somewhat slower in adopting the social media platform: the same study estimates that somewhere around $10 \%$ of the French population currently use it. Yet Twitter is becoming progressively more widely-known in France too, partly through the influence of politicians and journalists as early adopters, and indeed this has also been the case in several other countries (Grant, Moon, \& Busby Grant, 2010). Twitter has played a role in several political scandals taken up by the mainstream media in France, such as the controversial tweet sent by the country's First Lady, Valérie Trierweiler, during the 2012 French general election campaign (infra).

Today, there is considerable pressure on politicians in France to create a Twitter account (Brachotte \& Frame, 2011), yet the way they subsequently use the tool raises many questions in terms of strategic PR and image management. Indeed, PR specialists are quick to stress that Twitter can only be a valuable tool if used as part of a global PR strategy (Evans, Twomey, \& Talan, 2011; Grunig, 2009). Hwang suggests that strategic use of the tool by CEOs can contribute to improving perceptions of leadership and positively influence the image of the corporations they represent (Hwang, 2012). Can leading political

\footnotetext{
* Corresponding author.

E-mail addresses: aframe@u-bourgogne.fr (A. Frame), gilles.brachotte@u-bourgogne.fr (G. Brachotte).

1 According to the study carried out by Reputation Managment Consultancy Agency Augure (www.augure.com) and published in April 2014, 346 out of 577 MPs were had been active on Twitter at least once in the 30 days prior to the beginning of the study. A further 62 "inactive" accounts were recorded, placing the total number of MPs with accounts at 408.
} 
figures use Twitter to obtain similar goals? Much research carried out into the kinds of information tweeted by politicians, in various countries, suggests that the tool is often used by politicians principally for self-promotion, in the traditional topdown style of political communication (Grant et al., 2010; Larsson \& Kalsnes, 2014). By contrast, the platform is only rarely used to exchange information, debate or give insights into political processes (Golbeck, Grimes, \& Rogers, 2010; Lawless, 2012; Vergeer \& Hermans, 2013). However, some authors point have found evidence of differing styles of Twitter use among politicians, depending on their profile (Dang-Anh, Einspänner, \& Thimm, 2012; Jackson \& Lilleker, 2011; Sæbø, 2011) and others have proposed evidence of maturing patterns of usage (Grant et al., 2010) and of the influence of a small political elite within a national Twittersphere (Ausserhofer \& Maireder, 2013).

In many countries, and notably in the UK and US, Twitter has been used by politicians to $\mathrm{s}(\mathrm{t})$ imulate proximity by conveying details from the private sphere (Frame \& Brachotte, 2013; Frame, 2012; Jackson \& Lilleker, 2009). While this has been analysed as contributing to a broader trend towards the personalisation of politics (Stanyer, 2013), it is interestingly not the case in France, where a stricter division between public and private can be observed in political PR in general, including that on social media (Brachotte \& Frame, 2011). In the light of this observation, further qualitative research was carried out by the authors in order to gain insights into the specific ways French politicians were using Twitter as a strategic PR tool.

This paper draws on the results of this qualitative research, consisting in a series of five semi-directive interviews conducted with female French politicians active on the national level (MPs and senators), including current and ex-ministers from across the political spectrum. ${ }^{2}$ The politicians interviewed were encouraged to discuss in-depth their personal practices and representations of Twitter as a political PR tool, through a range of questions including the following topics: motivation of use, modes of access, time spent reading and writing, profile information, followers, best practises, evolutions in usage, evolutions in working practises, individual vs. team-run accounts, global social media strategy, public vs. private spheres, limits and resistance. The paper will draw on the declared and observed practises of the politicians, to analyse the way Twitter is being used as a political PR tool.

\section{Methodology}

For the purposes of this qualitative research, politicians were selected on the basis of several factors: (a) the fact they had an active account on Twitter, (b) their political profile and relative importance on the French national political scene, (c) the researchers' capacity to obtain a contact with them and (d) their willingness to participate in the study. Out of a total of twenty politicians contacted, five accepted to be interviewed, in person, by telephone or by Skype. These were:

- Isabelle Attard: MP for Calvados (Normandy) for the "Europe Ecologie - Les Verts" ecologist party. ${ }^{3}$

- Roselyne Bachelot: Health and Sports Minister and later Minister for Social Affairs under the presidency of Nicolas Sarkozy. Previously Minister for Social Cohesion, Roselyne Bachelot ended her 35-year political career in 2012, having lost her seat in the general elections, and resumed her previous career in journalism.

- Michèle Delaunay: Socialist MP for Gironde and Minister for the Elderly under the presidency of François Hollande from May 2012 to March 2014. ${ }^{4}$

- Catherine Morin-Desailly: Member of the "New Centre" party and Senator for the Haute Normandie area.

- Safia Otokoré: Vice-President of the Regional Council of Burgundy and chief communications advisor to Pierre Moscovici, Minister of Finance under the presidency of François Hollande.

The interviews were conducted between May 2013 and January 2014, each one lasting between 30 min and one and a quarter hours. Transcripts were subsequently submitted to the interviewees for validation. Table 1 resumes the main characteristics of the interviewees' Twitter accounts on the date of their respective interviews, including varying levels of activity on Twitter (measured in the number of tweets sent in the 30 days prior to the interview). ${ }^{5}$

Despite their varying levels of experience and activity on Twitter, the politicians interviewed clearly do not constitute a representative sample of the population studied, even if this were limited to the 150 female members of parliament. However, the objective of this qualitative research is not to seek to describe or characterise practises within the population as a whole, but rather to gain in-depth insights into the ways in which individual politicians seek to make use of the communication tool, their representations of it and of the "media logic" (Schulz, 2004) at work.

\footnotetext{
2 This research is part of a wider editorial project being carried out by the authors into the use of Twitter as a communication tool by female politicians and political journalists in France. Among the politicians selected for interviewed were representatives of the governing left-wing Parti Socialiste; the large right-wing party which had governed France until 2012 under Nicolas Sarkozy, Union pour un Mouvement Populaire; the small group of centre-right formations making up the Union pour la Démocratie Française; and the ecologist/Green Party group represented by Europe Ecologie - Les Verts.

${ }^{3}$ In December 2013, Ms Attard resigned from EELV to become first serving Member of Parliament to join the new left-wing political formation named "Nouvelle Donne".

${ }^{4}$ As Minister, Michèle Delaunay set up a specific Ministerial Twitter account, run principally by her team. The account included in this study is her "personal" account, set up before she became Minister and continued afterwards.

${ }^{5}$ Writing tweets is of course only part of the activity on Twitter, however, since politicians may spend much more time reading than writing tweets (cf. infra).
} 
Table 1

Interviews conducted with politicians and details of their accounts.

\begin{tabular}{|c|c|c|c|c|c|c|}
\hline Name, Twitter handle & Account since & Date of interview & $\begin{array}{l}\text { Accounts } \\
\text { followed }\end{array}$ & $\begin{array}{l}\text { Followers of } \\
\text { account }\end{array}$ & Tweets (total) & $\begin{array}{l}\text { Tweets ( } 30 \\
\text { days prior to } \\
\text { interview) }\end{array}$ \\
\hline Isabelle Attard, @TeamIsaAttard & $05 / 03 / 2012$ & $21 / 01 / 2014$ & 566 & 1789 & 4250 & 158 \\
\hline Roselyne Bachelot, @R_Bachelot & $22 / 02 / 2012$ & $24 / 06 / 2013$ & 253 & 43359 & 2064 & 75 \\
\hline Michèle Delaunay, @micheledelaunay & $24 / 02 / 2011$ & $30 / 01 / 2014$ & 1419 & 19400 & 19800 & 498 \\
\hline Catherine Morin-Desailly, @C_MorinDesailly & $02 / 05 / 2011$ & $20 / 01 / 2014$ & 714 & 2552 & 2873 & 56 \\
\hline Safia Otokore, @safiaotokore & $30 / 04 / 2009$ & $24 / 05 / 2013$ & 1431 & 5764 & 8868 & 333 \\
\hline
\end{tabular}

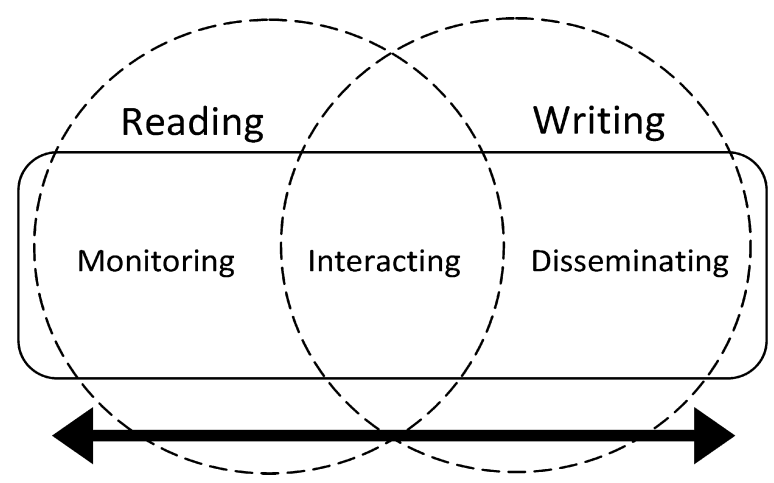

Fig. 1. Correspondence between activity on Twitter and 3 main communication functions.

\section{Twitter as a strategic PR tool}

One of the keys to understanding the use of Twitter by different politicians - their "Twitter styles" (Dang-Anh et al., 2012) - is to take into account their activity on the platform: time spent reading and writing tweets, whether the account is managed alone or also by the parliamentary attachés. Among the politicians interviewed, the practices reported were very different. Safia Otokoré, Roselyne Bachelot and Michèle Delaunay declare that manage their accounts entirely on their own. At the time of the interview, Michèle Delaunay also had a ministerial account (not included in this study), managed by her team, on which she occasionally retweeted messages from her personal account. Isabelle Attard and Catherine MorinDesailly state that their attachés contribute some of the (more factual) tweets posted on their accounts, though both claim to write over $50 \%$ of the tweets themselves. In the case of Isabelle Attard, the collective authorship of the account is identified both by its name (@TeamisaAttard) and the photo chosen, which shows the MP and her attachés, whose initials are given in the profile description.

The politicians also vary as to the time they declare devoting to reading and writing tweets. For all of the politicians questioned, these activities generally take place in "quiet moments": in the morning or the evening, when travelling, or when attending long meetings. Isabelle Attard and Safia Otokoré both consider that they spend most of their time reading (Isabelle Attard estimates that this represents around $85 \%$ of her time spent on the platform), whereas Michèle Delaunay and Catherine Morin-Desailly both consider that they spend more time tweeting. It should be noted this distinction is to a large extent artificial, since in practice users very often retweet and comment on other tweets they are reading. However, the way the individual politicians evaluate their activity is interesting in terms of their perceptions of the tool and its uses. As Fig. 1 suggests, from an analytical point of view, the major functions of Twitter as a (political) PR tool can be roughly divided between monitoring (mainly reading), interacting (reading and writing) and disseminating (mainly writing). Although the interviews and overviews of the tweets sent suggest that all of the interviewees exploit all of these different basic functions to some degree, it is interesting to note that perceptions (and practices) vary.

One of the most important functions of Twitter, according to the politicians, is its potential as a monitoring tool, to capture in real time dominant public sentiment towards a particular issue being debated on the social platform. Michèle Delaunay and Catherine Morin-Desailly both talk about "taking the temperature" of public opinion, whereas Roselyne Bachelot says that the network is "a useful sounding board". ${ }^{6}$ Isabelle Attard takes this logic further, not just using Twitter to see what is being said on a certain topic, but interacting with her followers and seeking out experts in a particular field while she is in parliament or working on a commission, debating or conducting interviews, in order to help her ask relevant and informed questions:

\footnotetext{
${ }^{6}$ Michèle Delaunay: “C'est une prise de température de l'opinion qui est agréable et rapide”. Catherine Morin-Desailly: “C'est une prise de température, une ambiance". Roselyne Bachelot: "[C'est un] réseau caisse de résonance très utile”.
} 
Twitter has great interactive potential. For example, when I'm in parliament, or debating with someone, users can say things like: "ask him why he didn't do such and such a thing". It opens a window of dialogue between those who are in a position to take part directly in the debate, like me, and those who aren't. It also helps me find relevant arguments when I'm interviewing people, by taking expert advice. And it is that dimension of being in touch with people who know certain things (legal texts, jurisprudence, etc.) which help me become more efficient, more relevant in the comments I make. ${ }^{7}$

Monitoring the activity on Twitter also contributes to what Jackson and Lilleker (2011) define as "constituency service": by following relevant accounts, conversations or topics, politicians are able to retweet and link to online resources which have significance for local constituents. The same is true concerning the politicians' particular subjects of interest or responsibility within their respective political formations. Retweets and hyperlinks, as well as comments and reactions, are ways of showing they are part of the debate.

On the production side, the politicians see the tool as a way to disseminate information quickly and effectively, "shortcircuiting the traditional press networks", in Isabelle Attard's words. "By posting information on Twitter, you multiply its impact by ten, by twenty or one hundredfold", ${ }^{8}$ she says. If Twitter is indeed perceived as an instrument for direct communication with voters (infra), politicians also consider that one of their main targets through this platform is journalists, who continue to act as an important relay for their messages. Safia Otokoré remarks that Twitter is often used by politicians to refute statements publicly, and that they are able to do so much more quickly and easily than by using an official press release. They know that journalists will systematically check their Twitter account for reactions when preparing a story.

It is paradoxical to note, however, following interviews with a panel of political journalists, that although the journalists do indeed follow politicians' accounts, they only tend to read those they deem interesting or original, if any. They declare themselves much more interested in what other journalists have to say than in standard politicians' tweets, generally perceived as factual and boring. Indeed, it would appear that politicians are just as dependent on journalists' Twitter accounts as the opposite, if not more so. In her capacity of chief communications advisor to the Minister of Finance, Safia Otokoré says that she followed certain journalists whom she had identified as useful sources, and would check their accounts regularly, knowing that if sensitive information had leaked from the Finance Ministry, she would find evidence of it there. Similarly, she would expect any important newspaper articles to be commented on Twitter by these journalists, and so Twitter became her first port of call when preparing her ministerial press review. "When I get up in the morning, I read Twitter instead of the AFP [Agence France Presse]", ${ }^{9}$ she says, though underlining that this did not replace her subsequently reading all of the main newspapers published that morning. Twitter can thus be integrated into politicians' (teams') media monitoring strategies, in order to quickly identify major stories or specialised subjects being discussed.

Another major communicative function of Twitter, aimed at voters in general, is that of informing about, justifying and explaining political decisions. In this regard, both Isabelle Attard and Roselyne Bachelot talk about the challenge of writing clearly and concisely in 140 characters, which Roselyne Bachelot compares to the exercise of the "one-minute speech" in front of the European Parliament. "A positive thing about Twitter is that it makes you think", she comments, referring to the tool as a "conceptualisation aid". ${ }^{10}$ Isabelle Attard notes that her parliamentary attachés often find more punchy formulations when retweeting her speeches than they do when preparing the originals.

However, it would be misleading to suggest that the majority of tweets were carefully-crafted condensed sound-bites of political wit and genius. Most tweets concern the politicians' everyday activities linked to their constituency or their particular mandate or area of interest, and refer to visits, events or important decisions which have been made. For her part, Safia Otokoré makes a point of using Twitter to inform local voters about decisions made behind closed doors, when these decisions are going to be made public and serve as a foundation for policy. Taking the example of the Burgundy Regional Council, she says that more and more spending decisions tend to be made far from the public eye. These decisions are often complex and hence their motivations liable to being misconstrued by the public. Twitter, she says, can be a helpful tool to explain, in real time, the perceived stakes which motivated certain decisions made, to voters (and journalists) who will not have immediate access to the minutes of the meetings in question. She adds that the platform is a way of reaching young people, who won't generally read reports or classical political information, but who will most likely read tweets. In this respect, finding the right words to share information in a timely tweet can be a way of informing the debate in the public sphere, as well as a way of encouraging voters to accept difficult political decisions.

\footnotetext{
7 “Twitter permet une interactivité énorme et fabuleuse par exemple, quand je suis à l'Assemblée ou en train de débattre avec quelqu'un, les twittos peuvent me dire 'demandez-lui pourquoi il n'a pas fait ça'. C'est une porte ouverte à la discussion entre ceux qui peuvent intervenir en direct comme moi et ceux qui ne le peuvent pas. Cela permet d'être pertinente face aux personnes que l'on auditionne, en ayant les conseils des experts. C'est la dimension de communication avec des gens qui sont au courant de certaines choses, textes de lois, jurisprudence etc.... qui va me rendre plus performante, plus pertinente dans mes propos". All translations into English are by the authors of this paper.

8 “[Cela s"appelle clairement] court-circuiter les réseaux de presse traditionnels. En envoyant sur Twitter, vous multipliez par dix, vingt ou cent, son impact."

9 "Le matin, quand je me lève, au lieu de lire l'AFP, je lis Twitter".

10 "Le côté heuristique de Twitter est en soi intéressant. [. C'est] un outil d'aide à la conceptualisation".
} 


\subsection{Personal interactions}

However, Twitter is not perceived by the politicians solely as a tool for disseminating or "broadcasting" information. The interactive function is also present, to some degree, on all of the accounts studied, despite the fact that studies tend to show that very few politicians take the time to interact systematically with their followers or with the people who send them messages (Lawless, 2012; Sæbø, 2011). The most prolific user in the study, Michèle Delaunay, says that she makes a point of always replying to messages addressed to her - except when they are insulting - and this is appreciated by her correspondants: "Sometimes I meet people who tell me: "we're friends on Twitter and you replied to my tweet". It marks people when a minister replies to them in person". ${ }^{11}$

Twitter is also widely used by politicians to interact with one another, whether to associate themselves with, lend support to or draw attention to "positive" actions, often carried out by members of their political "family", or to condemn or point the finger at words or deeds they judge negatively, usually associated with members of the opposition parties. These fairly predictable and banal interactions, arguably serve not so much to sway minds, as to curry favour with the existing party supporters who relay them. However, an interesting spin-off can be observed in the form of what might be termed "live" tweets during parliamentary debates in the Assemblée Générale. Isabelle Attard remembers the salutary effect of one such "parallel debate" during the parliamentary debate on the bill proposing same-sex marriage, when MPs in the majority were instructed not to react verbally to provocative opposition stalling tactics:

It happened during the debate about same-sex marriage in the Assemblée, when majority MPs had been told not to speak, not to reply or debate since that gave the opposition more speaking time. But it was pretty hard not to react to what we were hearing - it was a big ask. Luckily we created a parallel debate on Twitter that gave us a safety valve through which we could let off steam. ${ }^{12}$

One final interactive function of Twitter, the possibility to send direct messages, has also opened up new possibilities for politicians in opposing parties to interact discreetly, according to the interviewees. Indeed, "DMs" provide an alternative communication channel to complement existing ones. Whereas email might be seen as too official, and politicians might not have access to an opposition member's mobile phone number or feel able to send them a text message, then direct messages on Twitter can constitute a more acceptable form of communication. "If a person follows you, it means they'll accept direct messages", 13 explains Safia Otokoré, adding that she herself regularly exchanges with opposition party members through this channel.

\subsection{Impression management: cultivating a political persona on Twitter}

The appeal of communication by direct messages being that it escapes the public eye, it follows that all other messages sent on Twitter need to be compatible with the politician's public image. Indeed, impression management is an essential part of the way politicians use Twitter (Jackson \& Lilleker, 2011), and this concerns, as the saying goes, not just what they tweet, but the way that they tweet it. The politicians interviewed seemed to agree that communication on Twitter should not simply be about announcing political information in a flat or boring way. For Michèle Delaunay, "A good tweet includes a bit of humour. After all, Twitter is something quite jolly, quite quick, exciting with a recreational side to it. You put little comments that you wouldn't put on a very long and serious text. [It's got] a fun side". ${ }^{14}$ However, she makes a distinction between her personal account and her ministerial one: "I make sure that the official account remains as informative as possible about our activities. It should acknowledge the people I meet by including a photo, for example. It should say polite things, and use lots of pictures". ${ }^{5}$ For Catherine Morin-Desailly, including photos is also a way of illustrating her work: "I use lots of images, because I think my followers like to see where I am and it makes things more real and concrete", ${ }^{16}$ whereas for Isabelle Attard it is important to frame contents in an interesting way, without being offensive: "It's information, news, with a bit of insolent humour, without hurting anyone. Political discussion should remain dignified, above board. A good tweet is one you don't regret". ${ }^{17}$ While gentle humour is thus often identified as an appropriate tone for the platform, Roselyne Bachelot warns that Twitter users are apt to (intentionally) misinterpret jokes and wordplay. After a particularly harsh defeat of the French rugby team at the hand

\footnotetext{
11 “Des fois je rencontre des gens qui me disent “on est amis sur Twitter et vous m'avez répondu”. Et cela marque les gens qu'une ministre leur réponde personnellement".

12 “Cela s'est développé lors du débat du mariage pour tous à l'Assemblée où la consigne pour la majorité était de ne pas parler; de ne pas répondre, de ne pas débattre car cela redonnait du temps de parole à l'opposition. Ne pas réagir à ce que l'on entendait, c'était quand même délicat, c'était vraiment nous en demander beaucoup, heureusement par Twitter, on a créé un débat parallèle. Cela permettait une soupape de sécurité, de se lâcher".

13 "Si la personne vous suit, c'est qu'elle accepte les DM".

14 “Un bon tweet, c'est un peu d'humour. Twitter est quand même quelque chose d'assez gai, d'assez rapide, pétillant avec un côté récréation. On met une petite remarque que l'on ne mettrait pas sur un grand texte très sérieux. Un côté ludique".

15 “Sur le compte officiel, les consignes que je donne sont d'être aussi informatif que possible sur nos activités. Rendre hommage à ceux que l'on rencontrait, par exemple mettre une photo. Mettre des choses cordiales, de plus en plus de photos."

16 “Je tweete énormément avec des images, car je pense que mes abonnés sont sensibles à voir dans quelle situation je me trouve et puis je trouve qu'il faut rallier cela au réel et au concret".

17 “C'est déjà l'information, l'actualité, avec une petite pointe d'humour et d'insolence, sans blesser gratuitement et sans faire d'attaque sur le physique. Une discussion politique en restant digne, droit dans ses bottes. Un bon tweet c'est celui que l'on ne regrette pas".
} 
of the New Zealand All Blacks, she expressed her disappointment in what she saw as a humorous way, by tweeting "Black is black", ${ }^{18}$ only to be subsequently accused of racism. She says she now endeavours to keep her use of humour within the limits of the "politically correct".

Another important element in constructing the political persona is the profile photo and description chosen by the politician to present their account. Unlike Isabelle Attard's "team" photo and profile description (supra), the other politicians have all chosen what might be described as "dynamic-looking" self portraits. This is self-consciously the case of Michèle Delaunay, who explains:

It is a photo taken at the summer university in La Rochelle - a photo taken while tweeting - I chose it when I was an MP, and when I became Minister, someone told me, "that's not a very ministerial image". Of course that is true, but I said "I'm Minster for the Elderly and I want to show that elderly people are connected and dynamic". So I kept it almost as a challenge. ${ }^{19}$

Safia Otokoré's account exhibits what she describes as an "old photo", chosen to express the idea that "we can do serious things without looking serious or stiff" ${ }^{20}$ She explains that since she is a woman, and black, since she does not come from a political family and does not have an electoral mandate, many people refuse to give her legitimacy in her political role. In response to this, her strategy is to reject pretences and show herself as she is, and Twitter helps her to do that: "if you want to know who I am, you just need to look at my Twitter account". ${ }^{21}$ She uses the account to communicate indiscriminately with friends, family and colleagues, insisting that this authenticity is the key to her legitimacy in the eyes of voters, namely younger voters, who are looking for someone with whom they can identify and in whom they can believe.

Although not necessarily for the same reasons, Senator Catherine Morin-Desailly adopts a similar discourse, when asked for whom she tweets. Authenticity and simplicity are again presented as key values in the image she endeavours to portray through her Twitter account:

I speak in the same way to the different categories [of followers]. I try to be myself, the female politician working on her particular subjects and contributing to my political group. I don't ask myself too many questions and I don't go in for marketing communication. Internet users take me as I am, in my diverse functions and roles. ${ }^{22}$

Such strategies of (controlled) "authenticity" indeed seem well-suited to the Internet and Twitter in particular, where trust is often based on perceived transparency and communication suspected of being contrived or incoherent risks being scrutinised and denounced by users. However, these strategies appear to reach certain limits when it comes to the question of privacy.

\subsection{Public, personal and private spheres}

Unlike British and US politicians who may choose to construct an online persona linked to "family values", by portraying themselves in the role of a "normal" mother, father, spouse, etc. (Jackson \& Lilleker, 2009; Frame, 2012), the French politicians interviewed were all in overt agreement about the strict necessity to dissociate public and private spheres. This distinction is to be found at the heart of the French notion of citoyenneté, which supposes that while all citoyens have a right to respect their own beliefs in private, these beliefs must not impinge on the way they behave or how they expect to be treated in public. The private sphere is thus considered to be outside the political arena and constitutes a taboo in French political communication which does not exist to the same extent in the English-speaking world (Brachotte \& Frame, 2011).

All of the interviewed politicians were adamant that anything they defined as strictly private/intimate was out of bounds and that it would be unacceptable to tweet about it. However, there was not a strict consensus among the interviewees as to where the realm of the private sphere is considered to end, and, furthermore, they use an intermediary distinction between "private" and "personal", as Michèle Delaunay points out:

To make [my tweets] a bit more attractive, especially at the weekend, I've always written things about the birds in my garden or things which are both private but not private, I mean I never speak about personal things, never about my husband. Or rather it's personal but not private. I often make little personal comments which are outside the professional field. ${ }^{23}$

\footnotetext{
18 "Noir c'est noir". This is also a reference to the title and chorus of a well-known French pop classic by national idol Johnny Hallyday.

19 “C'est une image de l'université d'été de La Rochelle - on va les photographier en train de tweeter - je l'avais mise quand j'étais député et quand je suis devenue ministre, quelqu'un m'a dit, "ce n'est pas une image ministérielle", ce qui est vrai bien évidemment, mais j'ai dit "je suis ministre des personnes âgées et je veux montrer que les personnes âgées sont branchées, sont dynamiques". [.] Je l'ai gardé presque à titre revendicatif".

20 "On peut faire des choses sérieuses sans avoir l'air sérieux ou coincé".

21 "Si on veut savoir qui je suis, il suffit de regarder mon Twitter".

22 "Je parle de manière indifférenciée aux différentes categories [de followers]. J'essaye d'être moi-même, la femme politique qui travaille sur ses sujets et qui fait un investissement dans sa famille politique. Je ne me pose pas 36000 questions et je ne fais pas de marketing communicationnel. Moi, les internautes ils m’appréhendent dans la diversité de mes fonctions et de mon rôle".

23 “J'ai toujours mis, pour le rendre un peu plus attrayant, en particulier le week-end, une petite note sur les oiseaux de mon jardin ou des choses à la fois privée et pas privée, c'est-à-dire que je ne parle jamais de choses personnelles, je ne parle jamais de mon mari. C'est du personnel mais pas du privé. Je fais bien souvent de petites remarques personnelles qui sortent du champ professionnel".
} 
Roselyne Bachelot makes the same distinction when she talks about her passion for the opera, but says that she would never dream of tweeting about or exhibiting herself in a photograph with a male partner or children. These "personal" subjects are thus not directly political, but they seem designed to give their persona depth outside the political arena, and in many cases may be characterised as orchestrated image management. As Michèle Delaunay comments, "I'm not going to say 'I've got toothache this morning' or 'my husband is a pain in the neck"'.24

The politician who goes furthest in sharing what others might well construe as "private" information also dissociates herself unequivocally from American or British exploitation of the private sphere. If Safia Otokoré sends public tweets to her son to tell him that she loves him, knowing full well, she adds, that he would much rather she sent this information in a (private) direct message, she justifies this as part of her desire for transparency on Twitter. She puts these tweets on the same level as writing about things she qualifies as "intimate", such as tweeting a verse from a poem she appreciates. Yet she very firmly draws the line at things concerning what she defines as her "private life", circumscribed here to the people with whom she has romantic relationships.

Indeed, Otokoré's strategy once again appears different to that of the other politicians. ${ }^{25}$ Her use of social media is coherent with the ideal of freedom which she says motivates her use of Twitter. Born in French Somalia and having moved to France with her ex-husband, a professional footballer, Otokoré says, "It took me a long time to gain my personal freedom. Twitter is an extension of that same struggle". ${ }^{26}$ She says that she prefers Twitter to Facebook because it is more open and easy-to-use - everything is accessible to everybody; she finds it easy to retweet, to discover new information, to copy photos and so on, without having to first make "friends" with other users. She uses the microblogging platform to remain in touch with family, friends and colleagues all over the planet, and describes it as "a life without geographical boundaries". ${ }^{27}$

\subsection{Limits and restrictions on the use of Twitter}

Despite the "freedom" identified here by Otokoré and associated with the technical capacities of the platform itself, politicians' use of Twitter as a PR tool does come up against certain limits, which can be institutional, political, legal, social or symbolic in nature. Institutionally, MPs and ministers in particular are bound to respect certain forms of confidentiality, and indeed, as Michèle Delaunay reports,

When I became Minister, they told us "the less you tweet, the more we'll appreciate you”. And lots of my colleagues stopped altogether, and others cut down considerably. I continued and was happy to have people like Marie-Arlette Carlotti or Cécile Duflot saying to me, "when I saw you kept tweeting, I started up again”. You see, I broke the taboo and once again it was because I was protected by my status of Minister for the Elderly. I was seen as trying to give a dynamic image. [...] The Prime Minister's Office sometimes came down heavily on ministers, especially to begin with, but I was never in the firing line. ${ }^{28}$

Although she continued to tweet, Michèle Delaunay was always careful about what she posted and when, so as "not to compromise my ministerial function, by writing something which could reflect badly, or reporting something said during a cabinet meeting, where we know that even the most banal comments must not be repeated: my position commands total discretion". ${ }^{29}$

Political and even economic considerations also come into play. Safia Otokoré explains that she is careful when tweets anything related to the economy, since she is aware of the potential impact that her tweets as the Finance Minister's head of communications might have on the country's economy, via the financial markets. Where it is left to MPs' discretion as to what and when they tweet, differences of opinion and practices can sometimes cause tensions, as Isabelle Attard reports:

I reacted quite strongly, within my [parliamentary] group, when, during a group meeting, one of my colleagues sent a tweet revealing my position on a particular vote. I found it unacceptable that he should have tweeted that during the meeting and clearly told him to mind his own business, that he could tweet what he liked about himself, and that I should be free to choose what I tweeted about myself. We're not there to inform on one another. My aim is not to ban tweeting, but that people should only tweet information about themselves. These meetings are quite confidential, and I don't want to receive a call from Mediapart [a political blog] saying, "ah, so you voted against this measure?" We haven't received instructions on how to use Twitter, but several colleagues, especially on the right, have been tempted

\footnotetext{
24 “Je ne vais pas dire “j'ai mal aux dents ce matin", "mon mari est casse bonbon".

25 It should also be remembered that although she was chief communication advisor to the Minister of Finance and Vice-President of the Burgundy Regional Council, Safia Otokoré was the only politician interviewed who had not been elected to a national political mandate.

26 “J'ai eu du mal à avoir ma liberté individuelle. Twitter c'est un prolongement de ce combat-là".

27 “C'est la vie sans frontières géographiques".

28 "Au début du mandat de ministre, on nous a dit très clairement: "Moins vous tweeterez plus on vous aimera". Et beaucoup ont arrêté de tweeter et d'autres se sont fait très très rares. Moi, j'ai continué et j'ai eu le plaisir de voir que des gens comme Marie-Arlette Carlotti ou Cécile Duflot me disent “quand j'ai vu que tu continuais, je m'y suis remise". Vous voyez, j'ai brisé un peu le tabou et une fois encore, parce que je suis protégée par mon statut de ministre des personnes âgées. Parce qu'on a perçu ma démarche de vouloir donner une image dynamique. [...]. Le service de com' du premier ministre à quelquefois recadré sévèrement des ministres, au début surtout, et moi, je n'ai pas eu de soucis".

29 “Ne pas porter tort à ma fonction de ministre, en mettant des propos qui ne sont pas du niveau ou en rapportant une parole qui a été prononcée en Conseil des Ministres dont on sait que même si elles sont anodines, il ne faut pas les rapporter en outrepassant la réserve qui doit être la mienne".
} 
to regulate its use, proposing to ban it during government question time.... I find that totally ridiculous since it's a public session of parliament, not a private one: anyone can tweet about what is said from in front of their television set. $^{30}$

Twitter also comes up against certain more or less clearly-identified legal limitations, and indeed users may actively exploit the legal "grey areas" it presents. In recent years, in France, Twitter has become the main tool for users seeking to circumvent the media blanket ban on publishing election results before 8pm on Election Day, notably with the hashtag \#radiolondres (Mercier, 2013). In this context, Safia Otokoré also propelled herself into the media limelight on the evening of 6th May 2012, date of the French presidential election, by tweeting a photograph of prominent Socialist party members celebrating around François Hollande, almost 90 minutes before the $8 \mathrm{pm}$ watershed. She claims that she sent the tweet because it showed politicians displaying authentic emotions, in contrast with their usual rigid self-control, and that this was an image she wanted to share with the public. The subsequent controversial attention that the tweet provoked meant that it also proved to be a shrewd PR move.

As the popular saying goes, "there is no such thing as bad publicity". However, controversy is not always positive, even for politicians. Although not strictly a politician herself, Valérie Trierweiler, who was François Hollande's partner in 2012, and who thus found herself cast in the role of First Lady of France, sent an infamous tweet during the parliamentary elections, which explicitly encouraged the dissident Socialist Party candidate who just happened to be running against Hollande's expartner (and Socialist Party presidential candidate in 2007), Ségolène Royal. Many would argue that the ensuing scandal was damaging to the images of both Hollande and Trierweiler, and indeed the would-be Première Dame subsequently failed to win much popularity with the French people, during the time she remained with François Hollande. The "Trierweiler tweet" was but one of a series of political "gaffes" on Twitter. Though the publicity may be welcome at times - sending intentionally provocative tweets can even be a worthwhile strategy, notably for members of extremist and/or anti-establishment political formations - many politicians who have been caught up in such controversy have come to regret their inopportune tweets. Michèle Delaunay has several times sparked off indignant reactions from small groups of users on the platform, following what she describes as "unfortunate" tweets which, she claims, were insufficiently thought through on her part, taken out of context and/or voluntarily misconstrued. In such situations, Catherine Morin-Desailly warns about the dangers of getting caught up in the whirlwind which is the tempo of social networks generally, of reacting in a way which is not compatible with the politician's role.

Even though [Twitter] lets you react quickly and broadcast information, I think it is important not to act in haste but rather to take time for reflection and political analysis. The politician's role should not be to overreact and to find themselves in the heat of the moment, but rather to keep their distance, to analyse, to think critically. That's the major risk associated with social networks. It's important not to let oneself get caught up in their temporality. ${ }^{31}$

Finally, scandals provoked by tweets can serve to highlight the social and symbolic limits of Twitter as a political PR tool. The fact that they involve a public figure inevitably accentuates and amplifies the impact but also the intensity of such scandals, which can be particularly violent and insulting towards the politicians involved, as if the mere fact that they were writing on Twitter gave people the right to express themselves with no social constraints. Roselyne Bachelot describes Twitter as a particularly violent medium, and grimly comments that in her experience "not all people who tweet are perverts, but all perverts are on Twitter". Feelings of resentment or frustrated disagreement among members of the public, which might previously have been voiced only in front of the television set or among friends, can now be posted directly to the politician's Twitter account, where they may gain support and contribute to the user's notoriety, with virtually no risk of recrimination. Bachelot regularly receives attacks on her age and insults from activists from within her own party, who believe she betrayed them by leaving politics. Similarly, Safia Otokoré reports receiving racial and sexual insults.

In general, female politicians are unfortunately no strangers to insults, yet the extreme violence denounced here by the interviewees goes beyond what they might encounter at the hands of their male colleagues. As Isabelle Attard comments,

Twitter abolishes differences, removes barriers between elected representatives, ministers and presidents. Everybody is equal so we address whoever we want and, if they want to, they'll reply. Except that we should never forget who

\footnotetext{
30 “Moi, j'ai eu une réaction assez virulente, au sein de mon groupe, lors d'une réunion de groupe le mardi matin, de $10 \mathrm{~h} 30$ à $13 \mathrm{~h} 00$, où là je n'ai pas admis que pendant ce temps-là, un de mes collègues envoie un tweet en donnant ma position sur tel vote, je lui ai clairement dis qu'il s'occupe de ses oignons, qu'il tweete ce qu'il veut, et moi je tweete ce que je veux de ce qui me concerne. On n'est pas là pour faire un peu système de délation. Mon objectif n'est pas d'interdire de tweeter mais seulement les informations qui les concernent. Ce sont des moments assez confidentiels et je ne veux pas avoir d'appel de Médiapart pour me dire, "ah bon, vous avez voté contre". On n'a reçu aucune consigne sur l'utilisation de Twitter, mais certains ont été tentés de réguler, certains collègues plutôt à droite, ont proposé l'interdiction des tweets pendant les questions au gouvernement. . . c'est absolument ridicule, car ce n'est pas du privé mais du public donc rien n'empêche que quelqu'un qui regarde la télé de tweeter".

31 “Si à la fois cela permet de réagir vite et de donner de l'information, je trouve qu'il ne faut pas se précipiter et il faut garder le temps du recul et de l'analyse politique. Le rôle du politique ce n'est pas de sur-réagir et d'être dans l'immédiateté mais dans la distanciation, l'analyse, le recul. C'est cela le risque majeur des réseaux sociaux. Eviter l'effervescence".
} 
we're talking to, that we can't make jokes or talk as we would to a friend [. . . ] when in fact we're addressing a minister. We mustn't forget too quickly the hierarchical differences that structure society. ${ }^{32}$

This may be analysed as a reflection of the apparent incompatibility of two different systems: on the one hand the field of political communication, where verbal jousting is an everyday activity, but one which is strictly coded (Bouchet, Leggett, Vigreux, \& Verdo, 2005), and, on the other, the media logic of Twitter, affording almost total interactional freedom and relative anonymity to an undifferentiated mass of users. The openness and the instantaneousness of the platform, plus the lack of mediating gatekeepers, may be among the reasons which push politicians to adopt Twitter as a PR tool, but these same characteristics also place them in very close (virtual) proximity to (connected) members of the public, leaving them more exposed, in symbolic terms, than they would be, for example, to offline hecklers. This violence is a challenge in terms of PR and "crisis management": how to avoid it, how to deal with it and minimise its impact, how to avoid escalation. Like her fellow politicians, Roselyne Bachelot systematically blocks any accounts expressing extremist, aggressive or insulting opinions. As Michèle Delaunay remarks, "it is not my role to serve as a platform for people who are there to denigrate, who don't respect others and who express themselves in a vulgar way. ${ }^{33}$

\section{Conclusion}

As a qualitative approach to a non-representative sample of French politicians, this paper set out to provide insights into the ways that the five figures interviewed perceived and used Twitter as a strategic PR tool. The practices revealed are unsurprisingly the reflection of each individual politician, their image and their style, yet the study has enabled us to identify and analyse certain major functions of Twitter within a communication strategy: monitoring, dissemination, interaction, as well as certain institutionally, socially, or self-imposed limits to its use.

The key to the success of Twitter can be associated with the new opportunities it offers: for gauging public sentiment in real time, for following and responding to current affairs and specific topics, for informing various publics about actions and issues, for communicating directly and im-media-tely with voters, journalists or other politicians or stakeholders. Twitter is also an important medium for impression management, though politicians remain divided as to the extent to which they should adapt their practices to the logic and codes of the medium, and regarding the perceived limits private sphere.

Indeed, as a concluding question, we might ask how far political communication needs to/is able to adapt to the dominant ethos of Twitter, or vice versa. The politicians interviewed all seem aware that the classic top-down "broadcasting" strategy on Twitter seems to have had its day. Michèle Delaunay considers that a tweet saying: "at 4pm, I'm opening the primary school in Such-and-Such a village with Mr Such-and-Such ${ }^{34}$ is a "bad tweet". Although such tweets can still be found in the corpus, the interviews suggest that the politicians do endeavour to adapt their communication to Twitter's own specific media logic. However, the openness of social media also engenders uncontrolled exposure to anonymous criticism, and the violent excesses to which the politicians are at times subjected constitutes a real challenge, both in terms of PR and of deliberative democracy online.

\section{Acknowledgements}

The authors would like to thank Isabelle Attard, Roselyne Bachelot, Michèle Delaunay, Catherine Morin-Desailly and Safia Otokore for their precious time and for having agreed to take part in this study.

\section{References}

Ausserhofer, J., \& Maireder, A. (2013). National politics on Twitter. Information, Communication E Society, 16(3), 291-314. http://dx.doi.org/10.1080/ 1369118X.2012.756050

Baron, C. (2014). Profil, usage et pratiques des députés français sur Twitter [Etude]. Retrieved from http://www.augure.com/wp-content/uploads/2014/04/ radiographie-deputes-francais-twitter.pdf Accessed 02.06.14

Bouchet, T., Leggett, M., Vigreux, J., \& Verdo, G. (2005). L'Insulte (en) politique. Europe et Amérique latine du xixe siècle à nos jours. Dijon: Editions Universitaires de Dijon.

Brachotte, G., \& Frame, A. (2011). Appropriation et usages des TIC chez des ‘leaders' politiques en France et en Grande-Bretagne: Pratiques et discours. In F. Liénard, \& S. Zlitni (Eds.), La communication électronique, enjeux de langues (pp. 65-76). Limoges: Lambert-Lucas.

Dang-Anh, M., Einspänner, J., \& Thimm, C. (2012). Mediatisierung und Medialität in Social Media: Das Diskurssystem, Twitter. Sprache Und Kommunikation Im Technischen Zeitalter. Wieviel Internet (v) Erträgt Unsere Gesellschaft? 2, 68

Evans, A., Twomey, J., \& Talan, S. (2011). Twitter as a PR tool. Public Relations Journal, 5(1), 20.

Frame, A. (2012). Too many twits? Réseaux sociaux et mise en scène de l'intimité par les candidats aux élections législatives britanniques en 2010. In S. Crinquand, \& P. Bravo (Eds.), L'intime à ses frontières (pp. 77-91). Cortil-Wodon: E.M.E.

Frame, A., \& Brachotte, G. (2013). Les campagnes des compagnes: Mise en scène de la vie publique et privée. In S. Zlitni, \& F. Liénard (Eds.), La communication électronique en questions (pp. 387-402). Brussels: Peter Lang.

\footnotetext{
32 “Twitter abolit les différences, ne met pas de barrière entre les élus, ministres, présidents. Tout le monde est à égalité, donc, on interpelle qui on veut et répond qui veut. Sauf que, il ne faut jamais oublier à qui on s'adresse, et on ne peut pas faire des blagues ou s'exprimer comme si c'était avec un pote

[... ] alors que l'on s'adresse à une ministre. Il ne faut pas oublier trop vite les distances hiérarchiques de la société".

33 "Je n'ai pas à servir de plate-forme à des gens qui sont dans le dénigrement et qui n'ont pas de respect de la personne et sont trop vulgaires".

34 “Michèle Delaunay: à 16 h, j’inaugure avec Gilles Tartempion, l'école maternelle de tel village".
} 
Golbeck, J., Grimes, J. M., \& Rogers, A. (2010). Twitter use by the U.S. Congress. Journal of the American Society for Information Science and Technology, 61(8), 1612-1621. http://dx.doi.org/10.1002/asi.21344

Grant, W. J., Moon, B., \& Busby Grant, J. (2010). Digital dialogue? Australian politicians' use of the social network tool Twitter. Australian Journal of Political Science, 45(4), 579-604. http://dx.doi.org/10.1080/10361146.2010.517176

Grunig, J. E. (2009). Paradigms of global public relations in an age of digitalisation. PRism, 6(2), 1-19.

Hwang, S. (2012). The strategic use of Twitter to manage personal public relations. Public Relations Review, 38(1), 159-161. http://dx.doi.org/10.1016/j. pubrev.2011.12.004

Jackson, N. A., \& Lilleker, D. G. (2009). MPs and E-representation: Me, MySpace and I. British Politics, 4(2), 236-264. http://dx.doi.org/10.1057/bp.2009.2

Jackson, N., \& Lilleker, D. (2011). Microblogging, constituency service and impression management: UK MPs and the use of Twitter. The Journal of Legislative Studies, 17(1), 86-105. http://dx.doi.org/10.1080/13572334.2011.545181

Larsson, A. O., \& Kalsnes, B. (2014). 'Of course we are on Facebook': Use and non-use of social media among Swedish and Norwegian politicians. European Journal of Communication, http://dx.doi.org/10.1177/0267323114531383

Lawless, J. L. (2012). Twitter and Facebook:New ways for members of Congress to send the same old messages? In R. L. Fox, \& J. Ramos (Eds.), iPolitics: Citizens, elections, and governing in the new media era (pp. 206-232). New York: Cambridge University Press.

Mercier, A. (2013). Avènement du Twiléspectateur et hashtags contestataires. In P. J. Maarek (Ed.), Présidentielle 2012: Une communication politique bien singulière (pp. 165-200). L'Harmattan: Paris.

Sæbø, Ø. (2011). Understanding Twitter use among parliament representatives: A genre analysis. In E. Tambouris, A. Macintosh, \& H. de Bruijn (Eds.), Electronic participation (pp. 1-12). Berlin Heidelberg: Springer

Schulz, W. (2004). Reconstructing mediatization as an analytical concept. European Journal of Communication, 19(1), 87-101. http://dx.doi.org/10.1177/ 0267323104040696

Stanyer, J. (2013). Intimate politics: Publicity, privacy and the personal lives of politicians in media saturated democracies. London: John Wiley.

Vergeer, M., \& Hermans, L. (2013). Campaigning on Twitter: Microblogging and online social networking as campaign tools in the 2010 general elections in the Netherlands. Journal of Computer-Mediated Communication, 18(4), 399-419. http://dx.doi.org/10.1111/jcc4.12023 